\title{
PELAKSANAAN KEDAULATAN NEGARA ATAS PENGELOLAAN SUMBER DAYA ALAM MELALUI MEKANISME PERSYARATAN PERDAGANGAN
}

\author{
I Wayan Titib S dan A Indah Camelia \\ Fakultas Hukum Universitas Airlangga \\ indah_camelia03@yahoo.co.id
}

\begin{abstract}
The trade between countries is the main important key to increase people's prosperity. It is mainly because the prosperity can be measure with nation's balance of trade. However, the trade has to be adjusted to the national resources and has to think of nation's souvereignty. In everyt trade between countries, there will be a condition in which souvereinty will be interefered by one of the member of the trade-for example in forms of pure trade or exploitation nation resources. Therefore, the requirements of trade between two members of trade are needed in order that it won't interfere by nation's souvereignty and also won't exploit all of nation resources
\end{abstract}

Keywords: Souvereignty, Trade, Nation resources

\begin{abstract}
Abstrak
Perdagangan antara Negara merupakan suatu kunci terpenting dalammeningkatkan kesejahteraan rakyat, hal ini dikarenakan tingkat kesejahteraan dapat diukur dari neraca perdagangan dalam suatu Negara, akan tetapi sekalipun demikian kegiatan perdagangan tersebut haruslah disesuaikan pula dengan sumber daya nasional suatu Negara dan harus pula memperhatikan kedaulatan suatu Negara, dalam perdagangan antar Negara ada suatu kondisi dimana kedaulatan tersebut akan terganggu oleh intervensi salah satu pihak dalam kegiatan perdagangan tersebut, baik dalam bentuk perdagangan murni maupun dalam ekploitasi sumber daya nasional suatu Negara, oleh karena itu amatlah sangat diperlukan suatu upaya persyarartan perdagangan yang harus disepakati oleh kedua belah pihak supaya kegiatan tersebut tidak mengganggu kedaulatan suatu Negara sekaligus tidak menghabiskan sumber daya nasional secara eksplisit.
\end{abstract}

Kata kunci: Kedaulatan, Perdagangan, Sumber Daya Nasional

\section{Pendahuluan}

Negara memiliki karakter yuridis yang melekat secara multak yang disebut kedaulatan. Salah satu bentuk manifestasi kedaulatan adalah kekuasaan penuh dalam mengelola sumber daya alam yang dimiliknya. Termasuk dalam pelaksanaan kedaulatan tersebut adalah hak untuk mengatur perdagangan sumber daya alam melalui pembentukan persyaratanpersyaratan perdagangan produk tertentu yang diberlakukan di dalam wilayah negara ${ }^{1}$. 
Namun dalam implementasi pengelolaan sumber daya alam, berpotensi berbenturan dengan kepentingan dan hak negara lain. Sehingga muncul isu pembatasan atas kekuasaan pengelolaan sumber daya tersebut yang dilandasi atas perlindungan lingkungan hidup. Implikasinya bahwa dalam pelaksanaan hak tersebut negara harus memperhitungkan kepentingan perlindungan lingkungan, baik lingkungan dalam batas-batas wilayah negara maupun di luar yurisdiksi negara yang bersangkutan.

Dalam menerapkan kedaulatannya negara tidak diperkenankan untuk memberlakukan persyaratan-persyaratan perdagangan nasionalnya secara ekstra yurisdiksional, sekalipun hal ini ditujukan untuk kepentingan perlindungan lingkungan di negara pengekspor. ${ }^{2}$ Pada praktiknya hal tersebut seringkali menimbulkan pertentangan antara negara maju dan negara berkembang dalam lingkup perdagangan internasional. Umumnya negara maju menerapkan standar lingkungan lebih tinggi, cenderung memaksakan berlakunya standar-standar lingkungan nasionalnya terhadap negara sedang berkembang dengan dalih perlindungan lingkungan global. Sementara negara berkembang seringkali mempergunakan dasar kedaulatan atas sumber daya nasional dan larangan diterapkannya persyaratan-persyaratan perdagangan secara ekstrayurisdiksi sebagai cara untuk menolak pemberlakuan standar

kemudian dimuat lagi dalam Prinsip 2 Deklarasi Rio.

${ }^{2}$ Sands, Phelippe, Principles of International Environmental Law I, Frameworks, Standards and Implementation, ManchesterUniversity Press, Manchester, 1995, hal. 188. lingkungan dari negara maju terhadap produk ekspornya. ${ }^{3}$

Pertentanganperdaganganinternasional dengan pelaksanaan kedaulatan atas sumber daya alam, juga dipicu oleh ketidaktegasan rumusan ketentuan Pasal XX GATT/WTO yang berbunyi:

Subject to the requirement that such measures are not applied in a manner which would constitute a means of arbitrary or unjustifiable discrimination between countries where the same condition prevail, or a disguised restriction on international trade, nothing in this Agreement shall be construed to prevent the adoption or enforcement by any contracting party of measures:

$\cdots$

(b) necessary to protect human, animal or plant life or health;

(g) relating to conservation of exhaustible natural resources if such measures are made effective in conjunction with restrictions on domestic production or consumption.

Ketentuan Pasal XX GATT inilah yang sering menyebabkan terjadinya perselisihan disebabkan terlalu umumnya pengecualian-pengecualian yang termuat dalam kalimat "necessary to protect human, animal or plant life or health" dan "relating to conservation of exhaustible natural resources...". Sehingga masing-masing negara mempunyai pemahaman sendiri mengenai hal ini dengan menentukan

${ }^{3}$ Steinberg, Richard H., "Trade-Environment Negotiations in the EU, NAFTA and WTO: Regional Trajectories of Rule Development", dalam American Journal of International Law, Vol. 91, No. 2, April 1997, hal. 232. 
persyaratan-persyaratan perdagangan yang dianggap sesuai dengan ketentuan Pasal tersebut.

Putaran Uruguay berusaha mempersempit kemungkinan terjadinya perselisihan dalam masalah ini melalui persetujuan-persetujuan mengenai standar sanitasi dan phitosanitasi serta persetujuanpersetujuan mengenai hambatan teknis dalam perdagangan. Dengan demikian WTO memungkinkan pemberlakuan standar-standar tertentu bagi produk asing yang akan diimpor ke suatu negara sepanjang didasarkan pada persyaratan metode proses dan produksi yang berkaitan dengan produk (product-related requirements). ${ }^{4}$ Persetujuan tersebut juga mensyaratkan bahwa hambatan dilakukan tidak melampaui kebutuhan (not more than necessary) dan ditujukan untuk memenuhi tujuan perlindungan lingkungan, kesehatan dan keselamatan yang diperkenankan oleh ketentuan WTO. ${ }^{5}$ Penentuan persyaratan sanitasi dan phitosanitasi harus didasarkan pada landasan ilmiah berdasarkan analisa risiko dengan memperhatikan faktorfaktor ekonomi yang relevan, seperti: kerugian potensial dalam produksi dan penjualan apabila terjadi penyebaran hama atau penyakit; beaya pengendalian dan pembasmian di wilayah negara pengimpor; dan aspek manfaat relatif terhadap beaya untuk membatasi risiko. ${ }^{6}$ Karena sifatnya

\footnotetext{
${ }^{4}$ OECD, Processes and Production Methods (PPM): Conceptual Framework and Considerations on the use of PPM-Based Trade Measures, OLIS, Paris, 1997, hal. 14.

5 Persetujuan Akhir Putaran Uruguay mengenai Persyaratan Sanitari dan Phitosanitari, Pasal 2(2) dan 2(3).

6 Ibid., Pasal 5(1).
}

yang ilmiah, maka pendekatan yang berbeda akan menghasilkan standar yang berbeda pula, oleh karena itu WTO menegaskan perlunya pengembangan dan penerapan standar-standar yang bersifat internasional ${ }^{7}$ untuk mencegah digunakannya standar tersebut sebagai hambatan tersembunyi. ${ }^{8}$

\section{Perumusan Masalah}

Dari uraian permasalahan di atas, maka teridentifikasi persoalan-persoalan apakah prinsip kedaulatan atas sumber daya nasional dapat diselaraskan dengan prinsip penghapusan hambatan-hambatan perdagangan dengan kepentingan perlindunganlingkungandalamperdagangan internasional?

\section{Metode Penelitian}

Penelitian ini merupakan penelitian hukum (legal research), yang berkaitan dengan kegiatan yang bersifat akademis. Penelitian ini mengarahkan analisisnya terhadap latar belakang, dan dinamika pengaturan serta analisis teori-teori yang terkandung dalam kedaulatan negara atas sumber daya dan persyaratan perdagangan internasional. Dan juga penelitian ini merupakan penelitian kepustakaan (library research). Bahan hukum yang digunakan dalam penulisan ini adalah bahan hukum primer dan bahan hukum sekunder. Bahan hukum primer diperoleh dari peraturan perundang-undangan nasional, perjanjian-perjanjian internasional, dan putusan penngadilan. Sedangkan bahan hukum sekunder diperoleh dari buku teks/literature, artikel dalam berbagai sumber ${ }^{9}$. Sedangkan Pendekatan masalah

\footnotetext{
7 Ibid., Pasal 3(3).

8 Ibid., Pasal 5(5).

9 Peter Marzuki,"Metode Penelitian Hukum",
} 
yang digunakan adalah pendekatan perundang-undangan (statute approach) dan pendekatan teori (theoritical approach $)^{10}$. Pendekatan perundangundangan dimaksudkan melakukan kajian dan analisis substansi terhadap peraturan perundang-undangan nasional maupun konvensi-konvensi internasional yang berkaitan dengan pengelolaan wilayah pesisir, khususnya mengenai kedaulatan negara atas sumber daya dan persyaratan perdagangan internasional.

\section{Kedaulatan Atas Sumber Daya Nasional}

Negara merupakan subyek hukum utama di dalam hukum perdagangan internasional, dan juga sebagai subyek hukum yang paling sempurna. Hal ini dikarenakan negara merupakan satu-satunya subyek hukum yang memiliki kedaulatan. Berlandaskan kedaulatan tersebut, negara memiliki wewenang untuk menentukan dan mengatur segala sesuatu yang masuk dan keluar dari wilayahnya ${ }^{11}$.

“... a state can absolutely determine whether anything from outside the state. The state would also have the power to determine the conditions on which the goods may be imported into the state or exported to another country. ... Every state would have the power to regulate arbitrarily the conditions of trade." ${ }^{\prime 2}$

Kencana, Jakarta, 2006, hal.49

${ }^{10}$ Enid Campell et all, "Legal Research Material And Methods", Thirth Edition, N.S.W Singapore 1988, hal 276.

${ }^{11}$ Hercules Boosen, International Trade Law on Goods and Services, Pretoria: Interlegal, 1999, hal. 2.

12 Ibid
Dengan kedaulatan ini, negara berwenang ${ }^{13}$ :

1. Membuat hukum yang mengikat segala subyek hukum lainnya, benda dan peristiwa hukum didalam yurisdiksinya (termasuk perdagangan).

2. Berperan baik secaralangsung maupun tidak langsung dalam pembentukan organisasi-organisasi (khususnya perdagangan) internasional di dunia.

3. Mengadakan perjanjian internasional untuk mengatur perdagangan

4. Subyek pelaku dalam posisinya sebagai pedagang ataupun pembeli.

Permasalahan yang kerap kali muncul saat terkait dengan atribut kedaulatan negara itu sendiri adalah negara tidak dapat dipaksakan untuk tunduk pada aturan negara lain, kecuali memang negara sendiri yang menundukan diri dengan sukarela ${ }^{14}$. Namun dalam perkembangannya, konsep kedaulatan ini mengalami pembatasan, terhadap 4 hal, yaitu :

1. Hukum internasional.

2. Hukum Nasional

3. Penundukan diri secara sukarela ataupun diam-diam

${ }^{13}$ Hans Van Houtte, The Law of International Trade, London

${ }^{14}$ Andrew W. Sheldrick, "Capacity, sovereign immunity and acts of state," Lew and Stanbrook, Interational Trade: Law and Practice, Bath: Euromoney, 1983, hal. 164. Yakni "Sovereign immunity is a long-established precept of public international law which requires that a foreign government or head of state cannot be sued without its consent. In its traditional form, this rule applied to all types of suit, criminal and civil, including those arising out of purely commercial transactions undertaken by the foreign sovereign." 
4. Klausula perjanjian yang menyatakan tunduk pada peradilan atau arbitrase dalam penyelesaian sengketa

Salah satu pembatasannya adalah pada hukum perdagangan internasional. Dalam perkembangannya aturan-aturan hukum perdagangan internasional lahir sebagian besar karena semakin banyaknya berbagai perjanjian internasional yang ditandatangani baik secara bilateral, regional, maupun multilateral antar negara ${ }^{15}$. Salah satu perjanjian multilateral yang menjadi rujukan hukum perdagangan adalah GATT (General Agreement on Tariffs and Trade) tahun 1947 di Genewa. GAAT diciptakan untuk tujuan mencegah terjadinya peperangan tarif dan mengupayakan perdagangan dunia berjalan secara bebas. Bahkan GATT disebut sebagai intenasionalisasi hukum perdagangan yang menjadi batasan pada kedaulatan hukum nasional ${ }^{16}$.

Sejak berdiri sampai saat ini aturanaturan perdagangan GATT telah berkembang dan mengalami perubahan yang cukup berarti. Terutama pada tahun 1986-1994, negara-negara anggota GATT telah sepakat untuk membentuk suatu badan atau lembaga internasional baru, yaitu WTO (World Trade Organization). Perubahan dari GATT ke WTO berdampak luas terhadap bidang hukum perdagangan internasional karena

${ }^{15}$ United Nations, Progressive Development of the Law of Internatoinal Trade: Report of the Secretary-General of the United Nations, 1966, para. 20; Chia-Jui Cheng, Clive M. Schmitthoff's Select Essay on International Trade Law, London: Martinus Nijhoff \& Graham \& Trotman, 1988, hal. 21.

${ }^{16}$ Schmitthoff, "The Unification of the Law of International Trade", 1968 JBL, London, hal 108. terbentuknya WTO bertujuan mengurangi hambatan perdagangan bebas.

\section{Tahun 1962 UNGA (United Nation} General Asembly) mengeluarkan suatu resolusi 1803 (XVII) mengenai konsep kedaulatan atas sumber daya nasional. Konsep kedaulatan atas sumber daya nasional adalah suatu perkembangan baru dalam dunia internasional terkait dengan kekuasaan negara dalam pengelolaan sumber daya alam yang dimilikinya. Implementasi prinsip ini akan berdampak pada kebijakan perdagangan dan regulasi investasi negara terkait dengan pengelolaan sumberdaya alam yang dimiliki. Konsep ini diadopsi oleh The Charter of Economic Rights and Duties of States tahun 1974, dengan mendefiniskan prinsip kedaulatan atas sumber daya nasional dalam bentuk yang lebih tersistematis. Dalam Pasal 2 charter ini dijelaskan lebih nyata mengenai hak negara atas sumber daya dan substansi pasal tersebut juga berpengaruh terhadap hukum perdagangan internasional ${ }^{17}$.

"1. Every State has and shall freely exercise full permanent sovereignty, including possession, use and disposal, over all its wealth, natural resources and economic activities.

2. Each State has the right:

(a) To regulate and exercise authority over foreign investment within its national jurisdiction in accordance with its laws and regulations and in conformity with its national objectives and priorities. No State shall be compelled to grant preferential treatment to foreign investment;

(b) To regulate and supervise the activities of transnational corporations within its national jurisdiction and take measures to

${ }^{17}$ Nico Schijver, "Sovereignty over natural resources, balancing rights and duties", Cambridge University Press, United Kingdom, 1997, hal.101-103 
ensure that such activities comply with its laws, rules and regulations and conform with its economic and social policies. Transnational corporations shall not intervene in the internal affairs of a host State. Every State should, with full regard for its sovereign rights, co-operate with other States in the exercise of the right set forth in this subparagraph;

(c) To nationalize, expropriate or transfer ownership of foreign property in which case appropriate compensation should be paid by the State adopting such measures, taking into account its relevant laws and regulations and all circumstances that the State considers pertinent. In any case where the question of compensation gives rise to a controversy, it shall be settled under the domestic law of the nationalizing State and by its tribunals, unless it is freely and mutually agreed by all States concerned that other peaceful means be sought on the basis of the sovereign equality of States $[\ldots]$ "

Dilain pihak Jerzy Makarscy dalam bukunya, lebih khusus mengelaborasi dalam prinsip-prinsip yang ada dalam sovereignty of state yang menitikberatkan pada unsur perdagangan sebagai berikut ${ }^{18}$ :

a. the principle of the selfdetermination;

b. the right of permanent sovereignty over natural resources;

c. the right of territory integrity;

d. prohibition of intervention.

${ }^{18}$ Jerzy Makarscy, The Principle of a New International Economic Order, Martinus Nijhoff, Publisher Dordrecht, Boston London, 1990, hal, 122-123
Penghapusan Hambatan Perdagangan Terhadap Kepentingan Lingkungan

Liberalisasi perdagangan internasional dapat diwujudkan dengan pemangkasan hambatan-hambatan, baik yang berupa hambatan tarif maupun non tarif. Penghapusan hambatan ini ditujukan agar terjadi kompetisi yang adil diantara pelaku-pelaku pasar, baik yang berasal dari dalam negeri maupun luar negeri, sehingga diharapkan terjadi persaingan bebas yang pada akhirnya harga-harga dapat bersaing secara kompetitif. ${ }^{19}$ Dan pembentukan hukumperdaganganberwawasanlingkungan saat ini masih dalam masa transisi, dimana beranjak dari konsep-konsep perdagangan dan lingkungan yang dikotomis, menuju terintegrasinya kedua konsep tersebut menjadi pembentukan hukum perdagangan berwawasan lingkungan yang dipengaruhi konsepsi pasar bebas dan didasarkan pada standar-standar teknis yang baku untuk memenuhi kebutuhan pasar. ${ }^{20}$

Perangkat utama yang tersedia bagi GATT untuk menangani masalah lingkungan adalah Pasal XX dan Persetujuan mengenai Hambatan Teknik terhadap Perdagangan.

\footnotetext{
${ }^{19}$ Lebih jauh lihat: Jackson, John H., et.al., Legal Problems of International Economic Relations, West Publishing, St. Paul, Minnesotta, 1995, hal. 15-37.

${ }^{20}$ M. Daud Silalahi membagi perkembangan hukum lingkungan (nasional) ke dalam tiga tahapan (generasi) yaitu: (1) generasi pertama yang didasarkan pada Deklarasi Stockholm; (2) generasi kedua yang didasarkan pada Deklarasi Rio; dan (3) generasi ketiga yang dipengaruhi oleh pasar bebas secara global dan proses desentralisasi yang lebih mengakomodasi nilai-nilai masyarakat lokal. Dengan demikian pembentukan hukum perdagangan berwawasan lingkungan berada pada masa transisi antara generasi kedua dan generasi ketiga. Lihat: Silalahi, M. Daud, Perkembangan Hukum Lingkungan Indonesia: tantangan dan Peluangnya, Pidato Pengukuhan Jabatan Guru Besar Fakultas Hukum Universitas padjadjaran, Bandung, 2000, hal. 2-8.
} 
Persetujuan mengenai Hambatan Teknis Terhadap Perdagangan memberikan kerangka untuk menangani masalah yang berkaitan dengan perdagangan di tingkat multilateral yang timbul akibat peraturan dan standar teknis. Namun implementasi Pasal XX GATT tidak boleh dibiarkan menjadi celah yang dapat dimanfaatkan oleh para proteksionis. Melanggar asas perdagangan bebas harus dilihat sebagai kekecualian, dan sifat kekecualian ini harus pula dipertahankan bila ada bahaya terhadap lingkungan.

Pada mulanya kedaulatan negara atas sumber daya nasional (permanent sovereignty over natural resources) adalah sebuah celah yang dapat digunakan oleh negara proteksionis yang untuk menghambat liberasisasi perdagangan. Apalagi dengan adanya pasal XX semakin mempertegas alasan negara proteksionis untuk melakukan hal tersebut. Selama beberapa lama permasalahan tersebut menjadi hambatan bagi pertumbuhan perdagangan global. Maka dari itu praktisi dunia usaha menawarkan solusi berupa pembentukan suatu standar internasional, yang bertujuan untuk menyeragamkan(menyelaraskan) mutu dan standar perdagangan. Standar ini diharapkan mampu menjadi jalan tengah bagi kepentingan negara pengekspor (dengan standar produk sumber daya rendah) dengan negara penerima (dengan standar perlindungan tinggi). Terkait mekanisme penyelarasan tersebut memang tidak mudah dilakukan dalam praktiknya. Masalah tersebut sebenarnya sudah cukup lama disadari oleh bangsa-bangsa di dunia, termasuk organisasi dunia PBB. Sehingga dalam resolusi UNGA No 2102 (XX), PBB menyatakan bahwa ${ }^{21}$ :

"Conflicts and divergencies arising from the laws of different states in matters relating to international trade constitute an obstacle to the development of world trade."

Penghapusan hambatan perdagangan adalah menjadi tujuan utama dari badan perdagangan internasional (WTO), namun bila dihadapkan dengan konsep kedaulatan negara atas sumber daya memang akan ada pertentangan. Bahkan pada era tahun 1960an banyak negara yang pesimis akan dapat mempertemukan kedua kepentingan tersebut, tanpa meninggalkan yang lain. Sehingga sampai saat ini dalam praktiknya banyak negara yang masih menetapkan standar ganda dalam permasalahan kepentingan perdagangan dan kedaulatan negara atas sumber daya. Namun tuntutan liberisasi perdagangan menjadikan masyarakat internasional mulai banyak menciptakan hal-hal atau aturan-aturan yang dapat menjembatani kedua kepentingan tersebut.

Prinsip kedaulatan atas sumber daya alam nasional merupakan prinsip dasar dalam hukum lingkungan internasional. Prinsip ini pada dasarnya mempunyai konsep-konsep yang bertentangan dengan prinsip hukum perdagangan internasional yang cenderung mengarah pada penghapusan hambatan-hambatan. Dengan demikian usaha untuk menggabungkan kedua prinsip

\footnotetext{
21 United Nations, op.cit., para. 14.
} 
hukum ini ke dalam suatu rumusan aturan hukum perdagangan internasional yang berwawasan lingkungan, tentunya bukanlah persoalan yang mudah, terlebih lagi jika dalam pembentukannya juga diwarnai oleh perbedaan konsep dan kepentingan antara negara berkembang dan negara maju mengenai kedua bidang tersebut.

Hukum perdagangan internasional memberi batasan bagaimana negara-negara harus menyusun aturan-aturan dan kebijakan nasional termasuk di dalamnya mengenai masalah lingkungan. Di sisi lain, hukum lingkungan mengatur bagaimana negaranegara harus menyusun perekonomiannya terutama yang berkait dengan kebijakan investasi dan produksi agar sesuai dengan perjanjian yang telah diikuti. Sekalipun berbeda, namun terjadi interaksi diantara kedua cabang hukum tersebut, baik dalam lingkup nasional maupun internasional. ${ }^{22}$

Dalamhukumnasionalinteraksitersebut dapat dilihat dalam ketentuan-ketentuan mengenai subsidi, ekolabeling, investasi dan pembentukan standar-standar nasional melalui pembentukan penetapan persyaratan metode proses dan produksi. ${ }^{23}$ Dalam hukum internasional interaksi tersebut terlihat dari adanya persetujuan-persetujuan lingkungan internasional yang memuat persyaratanpersyaratan perdagangan, diantaranya adalah: Convention on International Trade in Endangered Species (CITES 1975), Montreal Protocol on Substance that deplete

\footnotetext{
22 IISD\&UNEP, op.cit., hal. 3.

23 Permasalahan mengenai PPM ini sedemikian penting dalam persoalan hubungan antara perdagangan dan lingkungan sehingga disebut sebagai jantung dari hubungan tersebut.IISD\&UNEP, Op.Cit., hal. 41.
}

Ozone Layer (1987), Basel Convention on the Control of Transboundary Movement of Hazardous Wastes and their Disposal (1992) dan Cartagena Biosafety Protocol to the 1993 Convention on Biological Diversity. ${ }^{24}$

Harmonisasi Prinsip Kedaulatan Atas Sumber Daya Nasional Dengan Prinsip Penghapusan Hambatan-Hambatan Perdagangan

WTO mendorong dilakukannya harmonisasi sistem sertifikasi dan labelisasi secara internasional sebagai alternatif pemecahan friksi liberisasi perdagangan dengan perlindungan lingkungan. WTO dan beberapa institusi khusus ISO dan IEC telah melakukan upaya-upaya untuk membentuk saling kesepemahaman dan persetujuan diantara negara-negara yang dituangkan dalam bentuk aturan-aturan atau prosedurprosedur yang memuat persyaratan untuk diterapkan secara nasional. Upaya-upaya juga dilakukan untuk meningkatkan transparansi diantara para produsen terkait dengan produk dan juga memenuhi standar konsumen dunia. , untuk melakukan harmonisasi persyaratan-persyaratan metode proses dan produksi serta melakukan konsultasi-konsultasi untuk memecahkan permasalahan-permasalahan yang menjadi perhatian bersama. ${ }^{25}$

WTO dapat diberi mandat untuk mempertanyakan tindakan suatu negara yang memberlakukan regulasi-regulasi lingkungan yang menyebabkan terjadinya

${ }^{24}$ Disamping persetujuan-persetujuan ini masih ada lebih dari 20 persetujuan MEA dari sekitar 200 persetujuan MEA yang memuat persyaratan-persyaratan perdagangan. Ibid., hal. 11-12.

${ }^{25}$ OECD, Processes..., op.cit., ha. 18. 
perlakuan diskriminatif terhadap produsen asing. ${ }^{26}$ WTO juga berhak untuk menguji apakah beaya-beaya tertentu dapat menjadi faktor-faktor gangguan bagi berlangsungnya arus perdagangan, ${ }^{27}$ namun WTO tidak berhak untuk menilai apakah faktor-faktor tertentu dapat menjadi keuntungan bagi perlindungan lingkungan. Berdasarkan alasan tersebut WTO menginginkan agar persetujuan-persetujuan multilateral mengenai lingkungan lebih berperan dalam mengatasi persoalan lingkungan dalam perdagangan. $^{28}$

Namun

$$
\text { mengharapkan }
$$

peran

persetujuan

$$
\text { multilateral }
$$
mengenai lingkungan akan menghadapi beberapa kendala yang disebabkan adanya kelemahan struktur didalamnya. ${ }^{29}$ Dalam hukum lingkungan institusi yang ada sangat banyak dan kompleks, ${ }^{30}$ mengikuti permasalahan-

${ }^{26}$ Kewenangan ini didasarkan pada Pasal I GATT tentang Prinsip Most Favour Nations dan Pasal III tentang Prinsip National Treatment.

27 Pasal XII GATT.

${ }_{28}$ Cosbey, Aaron, "Beyond the WTO: Finding Appropriate Homes for the Issues of Trade and Sustainable Development", makalah disampaikan pada Trade and Environment Conference, Pasific Basin Research Center Kennedy School of Government, Harvard University, 2930 April, 1994, hal. 5-6.

29 Struktur disini merujuk pada kerangka legal formal dari institusi-institusi yang berada dalam sistem/rejim yang bersangkutan, yang berupa: kelembagaan, komposisi dari lembaga-lembaga, kewenangan dan hubungan diantara lembaga-lembaga tersebut. Lihat: John P. Renninger , "What Structural Changes are Needed in the System of International Institutions?', dalam Renninger, John P. (ed), The Future Role of the United Nationsin in Interdependent World, Martinus Nijhoff Publishers, Boston, 1989, hal. 220.

${ }^{30} \mathrm{Hal}$ ini berbeda dengan rejim hukum perdagangan internasional yang dilaksanakan oleh suatu kesatuan kelembagaan yang sama dalam persetujuan-persetujuan perdagangan yang sama.Bahkan persetujuan-persetujuan perdagangan dalam setiap levelnya (baik multilateral, regional, maupun bilateral) mempunyai karakteristik dan lingkup pengaturan yang relatif sama. Pada saat ini kecenderungan setiap persetujuan perdagangan adalah penghilangan hambatan-hambatan diantara negaranegara peserta. Hal ini menjadi pokok pembahasan baik permasalahan yang sedang dihadapi. ${ }^{31}$ Keragaman institusi itu melemahkan rejim hukum lingkungan internasional. ${ }^{32}$ Persetujuan-persetujuan multilateral mengenai lingkungan umumnya bersifat voluntary dan kekuatan mengikatnya tidak cukup besar, sehingga berlakunya kurang efektif. Oleh karena itu berbagai pihak menginginkan adanya restrukturisasi terhadap rejim lingkungan internasional ${ }^{33}$ untuk menjadikannya lebih efektif dan efisien, ${ }^{34}$ dan dapat digunakan sebagai sarana pengembangan interaksi antara kebijakankebijakan ekonomi dan lingkungan dalam lingkup internasional. ${ }^{35}$

dalam GATT/WTO, APEC, NAFTA, AFTA, MEE, dan peretujuan-persetujuan perdagangan lainnya.

31 Kompleksnya masalah ini berhubungan dengan banyaknya keterkaitan persoalan lingkungan dengan bidang-bidang lainnya, sehingga Menteri Lingkungan Perancis yang pertama menyebut departemennya sebagai "le Minstere del'Impossible". Moltke, Konrad, International Environmental Management, Trade Regimes and Sustainability, IISD, Canada, 1996, hal. 7.

32 Misalnya, sejak tahun 1986, bersamaan dengan mulai diselenggarakannya Putaran Uruguay, telah terselenggara lebih dari 100 konferensi-konferensi internasional mengenai lingkungan yang hasilnya berupa rejim hukum lingkungan baru, persetujuan-persetujuan MEA baru, atau berupa pengembangan dari persetujuanpersetujuan yang telah ada sebelumnya.

33 Beberapa ahli menyebutnya rejim hukum internasional sebagai international environmental governance untuk bisa menjangkau keterlibatan baik sektor publik maupun privat dalam aktivitas ini, baik yang mempunyai peranan formal maupun informal. Moltke, Konrad von, Whither MEAs? op.cit, hal. 9-10.

34 Penguatan kelembagaan dalam hukum lingkungan ini penting bagi hukum perdagangan, sebab rejim hukum lingkungan yang kuat akan sangat menentukan keberhasilan pencapaian cita-cita yang diinginkan oleh rejim hukum perdagangan. Untuk itu diperlukan identifikasi cara-cara memperkuat keseluruhan sistem hukum lingkungan internasional, antara lain, dengan cara meneliti implikasi sejumlah persetujuan lingkungan multilateral yang penting dan melakukan perbaikan-perbaikan dalam masalah keorganisasian dalam hukum lingkungan internasional untuk lebih diarahkan pada penguatan kelembagaan rejim hukum lingkungan. Ibid., hal. 16.

35 Ibid., hal. 16. 
Harmonisasi tersebut akan lebih sulit dan kurang diminati jika berkenaan dengan harmonisasi persyaratan metode proses dan produksi yang non-product-related, apabila metode proses dan produksi tersebut tidak mempunyai dampak global atau lintas batas negara. Padahal, pengaturan persyaratan metode proses dan produksi yang non-product-related yang ketat dapat menimbulkan pengaruh positif bagi upayaupaya pembangungan berkelanjutan dengan dihilangkannya biaya-biaya (hambatan) tersembunyi akibat kegiatan-kegiatan yang tidak berwawasan lingkungan. ${ }^{36}$ Namun keinginan ini akan sulit untuk terlaksana karena negara-negara dijamin haknya untuk menyelesaikan permasalahan lingkungan domestiknya yang dilandaskan pada penilaian dan kebijakannya sendiri yang didasarkan pada kondisi ekonomi dan sosial negara yang bersangkutan. Hal ini dimungkinkan dengan didasarkan pada Prinsip 11 Deklarasi Rio:

"States shallenact effective environmental legislation. Environmental standards, management objectives and priorities should reflect the environmental and development context to which they apply. Standards applied by some countries may be inappropriate and of unwarranted economic and social cost to other countries, in particular developing countries".

Prinsip ini kemudian menjadi dasar bagi negara-negara untuk menerapkan standar tertentu dengan maksud tertentu. Bagi negara berkembang hal ini hanya

${ }^{36}$ Ibid., hal. 17. merupakan hambatan tersembunyi dari negara maju untuk melindungi kepentingan produsen dalam negeri karena produknya tidak mampu bersaing dengan produk impor yang dapat diproduksi dengan harga yang lebih murah.

Upaya yang dilakukan oleh masyarakat internasional untuk mengatasi hambatan ini adalah dengan alternatif unifikasi hukum atau harmonisasi hukum perdagangan internasional secara menyeluruh. Hal ini terdorong oleh adanya berbagai aturan hukum nasional yang kemungkinan berbeda antara satu sama lainnya. Perbedaan tersebut dikhawatirkan akan mempengaruhi kelancaran perdagangan itu sendiri. Untuk menghadapi masalah ini, sebenarnya ada 3 cara yang dapat dilakukan ${ }^{37}$ :

1. Sepakatuntuktidakmenerapkanhukum nasionalnya, namun menggunakan hukum perdagangan internasional untuk mengatur hubungan-hubungan hukum perdagangan antar mereka.

2. Apabila aturan hukum perdagangan internasional belum ada dan atau tidak disepakati oleh salah satu pihak, maka hukum nasional suatu negara tertentu dapat digunakan. Dilakukan melalui penerapan prinsip choice of laws ${ }^{38}$.

3. Unifikasi dan harmonisasi hukum aturan-aturan hukum perdagangan

${ }^{37}$ Huala Adolf, Hukum Perdagangan Internasional, Prinsip-Prinsip dan konsepsi Dasar, Bandung: Rajawali Press, 2004, hal. 32.

${ }^{38}$ Sudargo Gautama, Kontrak Dagang Internasional, Bandung: Alumni, 1977, hal. 26, bahwa Klausul choice of law tidak wajib sifatnya. 
internasional ${ }^{39}$.

Mekanisme unifikasi dan harmonisasi hukum dinilai sebagai cara yang paling efektifguna hindari konflik di antara sistemsistem hukum yang dianut oleh masingmasing negara. Unifikasi dan harmonisasi berarti upaya atau proses menyeragamkan substansi pengaturan aturan hukum yang ada. Perbedaan keduanya terletak pada derajat keseragamannya. Dalam unifikasi hukum (penyeragaman hukum) berati penghapusan dan penggantian suatu aturan hukum dengan sistem hukum yang baru ${ }^{40}$. Harmonisasi hukum (penyelarasan hukum) hanya berupaya mencari titik temu dari prinsip-prinsip yang bersifat fundamental dari berbagai aturan hukum yang ada (yang akan diharmonisasikan) ${ }^{41}$.

Upaya diatas telah dilakukan oleh badan-badan perdagangan internasional, khususnya oleh the World Trade Organization (WTO), the International Institute for the Unification of Private Law (UNIDROIT), The Hague Conference of Private International Law dan PBB khususnya the United Nations Commission on International Trade Law (UNCITRAL) dan the United Nations Conference on International Trade and Law (UNCTAD) ${ }^{42}$.

\footnotetext{
${ }^{39}$ United Nations, op.cit., para. 15.

${ }^{40}$ Chia-Jui Cheng, op.cit., hal. 109. UNCITRAL merupakan badan PBB yang mengurus hukum perdagangan internasional menggambarkan perbedaan kedua kata tersebut: "While the terms are closely interrelated,"harmonization" may conceptually be thought of as the process through which domestic laws may modified to enhance predictability in cross-border commercial transactions; and "unification" may be seen as the adoption by State of a common legal standard governing particular aspects of international business transactions" (http://www.uncitral.org/en-index.htm).

${ }^{41}$ Ibid

${ }^{42}$ Schmitthoff, Clive M., Commercial Law in
}

Badan-badan tersebut telah banyak menghasilkan perjanjian internasional baik yang bersifat hard law dan soft law guna mendukung harmonisasi hukum perdagangan internasional. Misalnya ada tahun 1979, GATT berhasil mengeluarkan The GATT Code on Technical Standards (Standard Code). Aturan Standard Code ini mendorong negara-negara anggotanya untuk mengharmonisasikan standar-standar produk domestiknya. Upaya ini ditempuh agar kebijakan negara-negara mengenai standar produk tidak menjadi penghalang bagi perdagangan dunia ${ }^{43}$.

Untuk menyelaraskan prinsip-prinsip lingkungan terhadap penghapusan hambatan perdagangan maka dunia internasional sepakat membuat suatu standar penggunaan ekolabeling dan sertifikasi hijau yang berlaku secara internasional. Sertifikasi ini disisi lain dapat dianggap sebagai hambatan terhadap produk ekspor, namun disisi lain dapat menjadi jalan tengah untuk menjembatani kepentingan Negara eksportir atas produk dan Negara penerima atas perlindungan lingkungan. Maka dari itu di tingkat internasional, dengan dorongan kalangan dunia usaha dibentuklah "International Standardization Organization" (ISO) dan International Electrotechnical Commission (IEC)membentuk "StrategicAdvisoryGroup on the Environment" (SAGE) pada bulan Agustus 1991. SAGE merekomendasikan kepada ISO akan perlunya suatu Technical Committee (TC) yang khusus bertugas

\footnotetext{
a Changing Economic Climate, London: Sweet and Maxwell, 1981, hal 24

43 Michael Trebilcock and Robert Howse, The Regulation of International Trade, London: Routledge, 1995, hal. 29.
} 
untuk mengembangkan suatu seri standar pengelolaan lingkungan yang berlaku secara internasional. Standar inilah yang diberlakukan terhadap semua produk yang digunakan sebagai solusi bagi kepentingan perdagangan, sehingga substansi Pasal XX tidak menjadi celah yang dapat digunakan untuk menghambat pertumbuhan perdagangan.

Sebenarnya dalam menentukan standarisasi perdagangan bukanlah hal yang mudah, apalagi jika standar tersebut harus menjadi solusi untuk liberasisasi perdagangan dunia. Berbagai aspek dan faktor pendukung harus menjadi landasan kerangka berpikir dalam penetapan standar. Aspek tersebut antara lain adalah keterkaitan standar dengan masalah-masalah sosial dan ekonomi dalam kehidupan manusia ${ }^{44}$. Hubungan antara aspek sosial, ekonomi dan kehidupan manusia terhadap penentuan standar dapat digambarkan dibawah ini :

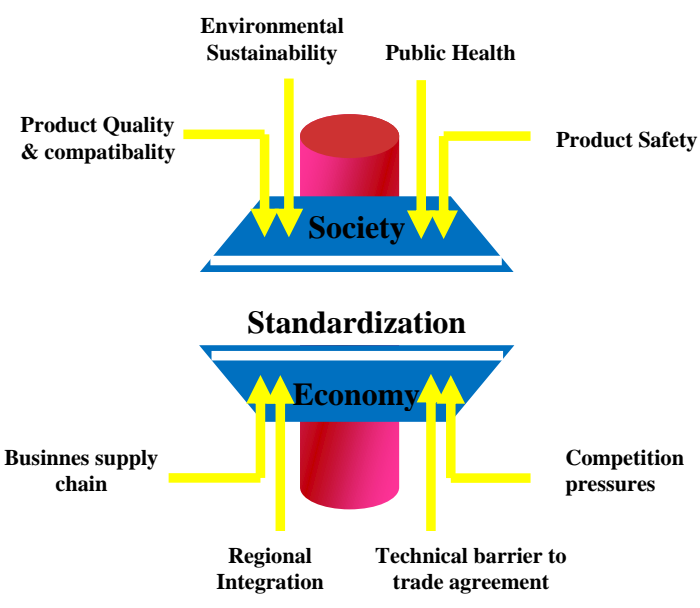

Gambar V.1 Pengaruh faktor ekonomi dan sosial terhadap kegiatan standardisasi ${ }^{45}$

${ }^{44}$ Badan Standarisasi Nasional, Buku Pengantar Standardisasi nasional, Edisi 1, Jakarta, 2009, hal 32-33

${ }^{45}$ Ibid
Berlandaskan pada kenyataan diatas maka penyelesaian permasalahan gap antara liberisasi perdagangan dan perlindungan lingkungan. Persyaratan-persyaratan perdagangan merupakan unsur dari kebijakan ekonomi, sosial dan lingkungan yang dapat mendukung pembangunan berwawasan lingkungan, artinya mencari suatu bentuk kebijakan yang mendukung unsur ekonomi, sosial dan lingkungan sekaligus. Mekanisme penyelesaian tersebut sama seperti yang digambarkan dalam penetapan sebuah standardisasi ${ }^{46}$. Dalam skema tersebut digambarkan faktor-faktor yang akan mempengaruhi suatu standar, yaitu :

1. Sosial \& lingkungan :
a. Kualitas produk dan kegunaan
b. Keberlanjutan lingkungan
c. Kesehatan masyarakat
d. Keamanan produk

\section{Ekonomi}

a. Rantai bisnis

b. Aturan teknis penghapusan perdagangan

c. Persaingan usaha

d. Penyelarasan (harmonisasi) secara regional

Penentuan sistem standarisasi juga bukanlah hal yang mudah. Berdasarkan penjelasan diatas maka dapat diketahui substansi kedua dari faktor standarisasi dipraktikkan oleh hampir semua negara. Karena substansinya sepertihalnya tujuan dari pembentukan WTO, sehingga

${ }^{46}$ Lihat gambar V.1 
setiap negara memiliki penafsiran dan melaksanakan aturan yang sama yang telah disepakati dalam WTO. Namun untuk faktor yang kedua sulit untuk dilakukan, karena sistem ini harus diciptakan untuk menjawab persoalan kepentingan sosial dan keberlanjutan lingkungan yang berbeda persepsi dan standar antara negara maju dan berkembang. Pada praktiknya saat ini masyarakat internasional khususnya dunia usaha telah menyepakati penggunaan standar internasional sebagai jalan tengah. Namun masih diperlukan suatu mekanisme harmonisasi hukum untuk semakin memberikan kepastian hukum. Pada dasarnya dalam melakukan harmonisasi hukum yang dilakukan penyelarasan $\operatorname{adalah}^{47}$ :

a. Harmonisasi regulasi dan tujuan unit sektoral

b. Tersedia mekanisme penegakan hukum antar unit yang berbeda

c. Koordinasi

d. Kebijakan lingkungan nasional

Mekanisme penerapan harmonisasi hukum dilakukan dengan cara $^{48}$ :

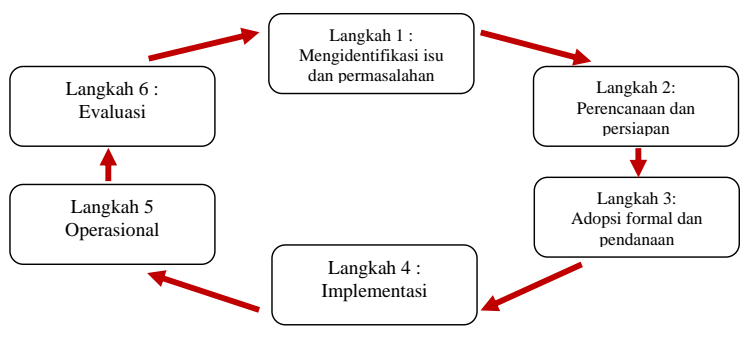

1. Identifikasi isu dan permasalahan

${ }^{47}$ Biliana cicin-sein, "Integrated Coastal and Ocean Management, concept and practice, Island Press, USA, 1998, hal 63

48 Telahdimodifikasiberdasarkanapayangditerangkan oleh Olsen, Will integrated coastal management programs be sustainable, the constituentional problem, Ocean and Coastal manajement, 1993 (1-3), hal 201-205
Dalam tahapan ini adalah melakukan inventarisasi dan identifikasi semua permasalahan dan kepentingan terkait dengan aspek perdagangan, pertumbuhan ekonomi, ekonomi, sosial, perlindungan lingkungan, kepentingan negara lain, organsisai regional, dan lainnya. Kemudian membahasnya dengan stakeholders sehingga didapatkan suatu bentuk outline dan rencana aksi.

2. Perencanaan dan persiapan

Berdasarkan rencana aksi yang telah disusun berdasarkan analisis permasalahan, dikembangkan menjadi suatu perencanaan yang lebih luas. Pada tahapan perencanaan harus disiapkan mekanisme koordinasi antar unit, regulasi, insentif, pengembangan struktur, terkait wewenang pemerintah (daerah atau pusat), dan kepentingankepentingan politik negara. Selain itu mulai nampak dasar kebijakan, arah, tujuan dan sasaran.

3. Adopsi dan pendanaan

Semua regulasi dan dasar kebijakan yang telah dibuat disahkan menjadi bentuk aturan hukum yang lebih formal dan komprehensif, serta memberikan dukungan pendanaan khusus untuk tujuan keberlanjutan program sehingga tujuan dari harmonisasi peraturan dagang dengan kepentingan lingkungan saling mendukung.

4. Implementasi, operasional dan evaluasi 
Tahapan ini adalah tahapan pokok dalam pembentukan mekanisme harmonisasi hukum dagang dengan lingkungan. Dalam tahap ini selain melaksanakan juga melakukan dilakukan evalusi sebagai langkah perbaikan.

\section{Kesimpulan}

1. Prinsip kedaulatan atas sumber daya alam nasional merupakan prinsip dasar dalamhukumlingkungan internasional. Prinsip ini pada dasarnya mempunyai konsep-konsep yang bertentangan dengan prinsip hukum perdagangan internasionalyang cenderung mengarah pada penghapusan hambatanhambatan. Maka harmonisasi hukum dinilai sebagai cara yang paling efektif guna hindari konflik di antara sistemsistem hukum yang dianut oleh masingmasing negara. Harmonisasi hukum (penyelarasan hukum) berupaya mencari titik temu dari prinsipprinsip yang bersifat fundamental dari berbagai aturan hukum yang ada (yang akan diharmonisasikan). Untuk menyelaraskan maka dunia internasional sepakat membuat suatu standar penggunaan ekolabeling dan sertifikasi yang berlaku secara internasional. Sertifikasi ini disisi lain dapat dianggap sebagai hambatan terhadap produk ekspor, namun disisi lain dapat menjadi jalan tengah untuk menjembatani kepentingan Negara eksportir atas produk dan Negara penerima atas perlindungan lingkungan.

\section{Saran}

1. Perlunya untuk melegalkan dan memberikan kepastian hukum untuk kepentingan keberlanjutan dari sistem perdagangan baru yang menjamin liberisasi perdagangan dan prinsip kedaulatan atas sumber daya. Meskipun saat ini telah ada mekanisme sertifikasi yang menjadi titik temu kedua kepentingan tersebut. Langkah yang paling tepat adalah dengan melakukan harmonisasi hukum (penyelarasan hukum) yakni mencari titik temu dari prinsip-prinsip yang bersifat fundamental dari berbagai aturan hukum yang ada (yang akan diharmonisasikan). Mekanisme menerapkan harmonisasi hukum adalah dengan: harmonisasi regulasi dan tujuan unit sektoral, tersedia mekanisme penegakan hukum antar unit yang berbeda, koordinasi serta membuat kebijakan yang mendukung lingkungan nasional. Setelah semua upaya tersebut dilakukan dalam bentuk regulasi nasional, baru kemudian membuat kerjasama multilateral dengan negara lain dengan tujuan yang sama.

\section{Daftar Bacaan}

Buku :

Adolf, Huala, Hukum Perdagangan Internasional, Prinsip-Prinsip dan konsepsi Dasar, Bandung: Rajawali Press, 2004

Badan Standarisasi Nasional, Buku Pengantar Standardisasi nasional, Edisi 1, Jakarta, 2009 
Boosen, Hercules , International Trade Law on Goods and Services, Pretoria: Interlegal, 1999

Campell, Enid et all, "Legal Research Material And Methods", Thirth Edition, N.S.W Singapore 1988

Cheng, Chia-Jui, Clive M. Schmitthoff's Select Essay on International Trade Law, London: Martinus Nijhoff \& Graham \& Trotman, 1988

Cicin-Sain, Biliana and Robert W Knecht, "Integrated Coastal and Ocean Management, concept and practice, Island Press, USA, 1998

Clive M., Commercial Law in a Changing Economic Climate, London: Sweet and Maxwell, 1981

Conway, Tom, A Framework for Assessing the Relationship between Trade Liberalization and Biodiversity Conservation, IISD, Canada, 1998

Departemen Perindustrian dan Perdagangan Kebijakan ekspor 2001-2010, Jakarta, 2004

Cosbey, Aaron, "Beyond the WTO: Finding Appropriate Homes for the Issues of Trade and Sustainable Development", Trade and Environment Conference, Pasific Basin Research Center Kennedy School of Government, Harvard University, 29-30 April, 1994

Gautama, Sudargo, Kontrak Dagang Internasional, Bandung: Alumni, 1977

Hartono, Sunaryati, "Penelitian Hukum di Indonesia Pada Akhir Abad ke 20", Alumni, Bandung, 1994

Houtte, Hans Van, The Law of International Trade, London, 1997
Kartadjoemena, H.S., GATT/WTO dan Hasil Uruguay Round, UI-Press, Jakarta, 1997

Makarscy, Jerzy, The Principle of a New International Economic Order, Martinus Nijhoff, PublisherDordrecht, Boston London, 1990.

Marzuki, Peter,"Metode Penelitian Hukum", Kencana, Jakarta, 2006

Olsen, Will integrated coastal management programs be sustainable, the constituentional problem, Ocean and Coastal manajement, 1993

Sands, Phelippe, Principles of International Environmental Law I,

Schijver, Nico, "Sovereignty over natural resources, balancing rights and duties”, Cambridge University Press, United Kingdom, 1997

Schmitthoff, "The Unification of the Law of International Trade”, 1968 JBL, London

Sheldrick, Andrew W., "Capacity, sovereign immunity and acts of state," Lew and Stanbrook, Interational Trade: Law and Practice, Bath: Euromoney, 1983

Silalahi, M. Daud, Perkembangan Hukum Lingkungan Indonesia: tantangan dan Peluangnya, Pidato Pengukuhan Jabatan Guru Besar Fakultas Hukum Universitas padjadjaran, Bandung, 2000

Steinberg, Richard H., "Trade-Environment Negotiations in the EU, NAFTA, and WTO: Regional Trajectories of Rules Development", American Journal of International Law, vol. 91, April, 1997 
Sumarni, Murti Salamah Wahyuni, "Metodologi Penelitian Bisnis:, Andi offset, Yogyakarta, 2008

United Nations, Progressive Development of the Law of Internatoinal Trade: Report of the Secretary-General of the United Nations, 1966

\section{Disertasi :}

Bruce, Robert A., Comparison of the FSC Forest Certification and ISO Environmental Management Schemes and their Impact on a Small Retail Business, Disertasi, University of Edinburgh Management School, 1998.

\section{Konvensi :}

Deklarasi Stokholm 1972

Deklarasi Rio 1992.

GATT 1947

\section{Jurnal \& Makalah:}

Frameworks, StandardsandImplementation, Manchester University Press, Manchester, 1995.

OECD, Processes and Production Methods (PPM): Conceptual Framework and Considerations on the use of PPMBased Trade Measures, OLIS, Paris, 1997
Bourke, J.J., "Trade Restriction and Their Future", dalam ECE/FAO Forest Product Annual Market Review, 19981999

Schoenbaum, Thomas J., "International Trade and Protection of the Environment: The Continuing Search for Reconciliation", dalam American Journal of International Law, vol. 91, April 1997

International Legal Materials, vol. 33

"North American Symposium on Understanding the Linkage between Trade and Environment", dalam Sustainable Development, vol. 41, no. 1., 14 Oktober 2000

\section{Internet :}

http://www.lei.co.id. Diunduh tanggal 10 Juni 2010

http://www.uncitral.org/en-index.htm. Diunduh 2 maret 2011

http://www.lei.co.id. diunduh tanggal 10 juni 2010

htp://www.wto.org. diunduh tanggal 10 juni 2011 